Rok XV (2020) | 2 (30)| S. 177-191

https://doi.org/10.12797/LV.15.2020.30.14

Anna Czelakowska ๑

Instytut Języka Polskiego Polskiej Akademii Nauk, Kraków

anna.czelakowska@ijp.pan.pl

\title{
UCZENI I ICH LOSY... - MIROSŁAW SKARŻYŃSKI JAKO BADACZ DZIEJÓW POLSKIEJ LINGWISTYKI
}

Słowa klucze: dzieje nauki, historia polskiej lingwistyki, początek językoznawstwa naukowego w Polsce, Mirosław Skarżyński

Keywords: history of science, history of Polish linguistics, the beginnings of scientific linguistics in Poland, Mirosław Skarżyński

„Na historię każdej nauki składają się nie tylko dzieje idei, koncepcji, badań, ale też losy instytucji naukowych i uczonych" (Robinson 2014: 13). Dzieje teorii i opisów zostawiają ślad w postaci prac naukowych, źródłami do dziejów instytucji pozostają gromadzone w nich dokumenty. Historię ludzi, ich losów i dokonań przechowują drukowane wspomnienia, pamięć innych osób, po latach zaś skrywają czasem gdzieś w archiwach dokumenty prywatne. Dla historii polskiego językoznawstwa zachowana i dobrze dostępna przy tym dokumentacja była do niedawna bardzo ograniczona, co przez wiele lat utrudniało badania z tego zakresu. Działalność Mirosława Skarżyńskiego stopniowo obejmowała jednak wszystkie wymienione „pola”. Najpierw swoją uwagę badawczą koncentrował on wokół historii myśli językoznawczej, później na wiele lat zajęły go przede wszystkim dzieje ludzi, którzy tworzyli kiedyś zaczątki językoznawstwa naukowego i jego struktury organizacyjne, a także wyszukiwanie i przygotowywanie materiałów do dalszych badań. Dzieje instytucji, o których po zebraniu wystarczających źródeł można było już powiedzieć coś nowego, stały się przedmiotem opisu dopiero w ostatnich latach pracy badawczej i w konsekwencji wątek ten w jego pracach nie został już rozwinięty. 
1. Badania Mirosława Skarżyńskiego w zakresie historii lingwistyki rozpoczęły się podczas przygotowywania rozprawy habilitacyjnej (Skarżyński 1994) poświęconej dziejom polskiej nauki o języku w latach 1817-1938, a więc w okresie między ukazaniem się ostatniego podręcznika Onufrego Kopczyńskiego ${ }^{1}$, tzw. gramatyki pozgonnej, oraz ostatniej przed wojną kompletnej gramatyki polskiej - Gramatyki współczesnej polszczyzny kulturalnej w zarysie Zenona Klemensiewicza. W latach 90. XX w. historia ogólna językoznawstwa i jego sytuacja w wieku XIX oraz pierwszych dziesiątkach następnego były już częściowo znane z dość licznych artykułów i kilku publikacji książkowych (np. Urbańczyk 1968, 1975, 1993; Bajerowa 1987 i in. ${ }^{2}$ ). W mniejszym stopniu poznano dzieje myśli językoznawczej - opracowano właściwie jedynie opisy słowotwórcze, ujmując je w trzech obszernych artykułach (Jadwigi Puzyniny, Renaty Grzegorczykowej i Zofii Kurzowej) w „Pracach Filologicznych” Z 1964 r. (Puzynina 1964; Grzegorczykowa 1964; Kawyn-Kurz 1964), oraz kształtowanie się teorii syntaktycznych (Podracki 1982). Skarżyński za przedmiot badań obrał więc podział wyrazów na części mowy oraz charakterystykę ich właściwości funkcjonalnych, tj. kategorii gramatycznych. Założeniem pracy było pokazanie ewolucji poglądów gramatyków na zagadnienia części mowy, przypadka, rodzaju oraz strony, czasu, aspektu i trybu³, najpierw w dobie przednaukowej, później zaś już naukowej, w okresie tworzenia się polskiego językoznawstwa o podstawach poznawczych.

Skarżyński dostrzegał zależność twórczości gramatycznej w XIX w. od okoliczności jej powstawania, a więc przede wszystkim odcięcia jej od naturalnej podstawy, którą jest językoznawstwo naukowe i refleksja teoretyczna. W tej sytuacji nie mogą dziwić ani opieranie się gramatyków (zdobywających wiedzę niemal wyłącznie $\mathrm{w}$ warunkach amatorskich) na dawno już nieaktualnej na Zachodzie racjonalistycznej teorii języka oraz na przekonaniu o uniwersalności ludzkiego myślenia, ani tego metodologiczne konsekwencje. Jako jedną z nich należy traktować nominatywną interpretację kategorii gramatycznych i poszukiwanie „uniwersalnych” wartości tych kategorii, nawet wówczas, gdy formy językowe polszczyzny nie dawały podstaw do ich wyróżnienia, jak było np. w odniesieniu do wartości czasu i trybu (Skarżyński 1994: 87-89, 95-99, 109).

Analiza gramatyk epoki przednaukowej prowadzi do - przewidywalnych zresztą - wniosków, że interpretacja języka, której dokonuje się na podstawie spekulatywnych teorii, bez szczegółowych badań materiałowych, a później refleksji po ich skonfrontowaniu z przyjmowaną teorią, musi prowadzić na manowce. Skarżyński daleki jest jednak od ostrego oceniania tego okresu. Zwraca zresztą uwagę nie tylko na

1 Jako książki będącej swoistym podsumowaniem wiedzy naukowej autora, dzięki czemu publikacja ta najsilniej wpłynęła na koncepcje językowe XIX-wiecznych gramatykopisarzy.

2 Ze względu na objętość tekstu literatura przedmiotu w tym miejscu musi zostać zredukowana. Szerszą, w tym adresy bibliograficzne gramatyk, zob. np. w: Skarżyński 1994, 2001.

3 Pominięte kategorie: osoby, liczby i stopnia, nie różniły się zasadniczo w opisie od ujęć współczesnych. 
zmiany paradygmatów badawczych i ich związek ze zmianami koncepcji opisu języka, ale też na próby wyjścia poza ogólnie przyjmowane schematy interpretacyjne.

Rozprawa Skarżyńskiego uświadamia trafność Kuhnowskiego spostrzeżenia o nawarstwianiu się wiedzy, pozwalającej później w nowy sposób interpretować kolejne zjawiska językowe i przyczyniającej się do ciągłego wzbogacania jej stanu. Książka jest też dowodem na to, jak zmiana metodologii (tj. przyjęcie metody młodogramatycznej, a także oddziaływanie psychologizmu) wpłynęła na zmiany w myśleniu o języku. Warunki po roku 1900 sprawiły zresztą, że okres ten (aż do roku 1938) był dla piśmiennictwa gramatycznego optymalny. Wykształceni w różnych ośrodkach naukowych badacze języka znali teorie powstałe w lingwistyce europejskiej, mogli je też wykorzystywać i rozwijać w odniesieniu do polskiego materiału językowego. Przyczyniło się to do powstania pierwszych polskich podręczników na poziomie akademickim (począwszy od gramatyki PAU z 1923 r.). Zresztą różnorodność podręczników: Stanisława Szobera, Tadeusza Lehra-Spławińskiego i Romana Kubińskiego, Henryka Gaertnera oraz Zenona Klemensiewicza, nie tylko odpowiadała zróżnicowanemu zapotrzebowaniu odbiorców na różnych poziomach wiedzy, ale też pozwalała poznać odmienne poglądy teoretyczne i metodologiczne ich autorów.

Wartość pracy Skarżyńskiego polega przy tym również na możliwości uświadomienia sobie tego, że rozwiązania, które dziś wydają się czasem oczywiste i bezdyskusyjne, także mogą być postrzegane jako arbitralne i zależne od paradygmatu, w którym się poruszamy.

Oczywiście, studia nad dziejami myśli językoznawczej przynoszą też nowe odkrycia, wpływające na konieczność uzupełnien i weryfikacji pewnych poglądów. Takie okoliczności skłoniły zresztą autora do przygotowania poprawionego i uzupełnionego wydania pierwszej wersji książki (Skarżyński 2001a). Poszczególne zagadnienia zostały w nim rozszerzone o dane dotyczące gramatyk wydanych po II wojnie światowej aż po Gramatykę wspótczesnego języka polskiego z 1998 r. Profesor stał się też pomysłodawcą rozprawy poświęconej ewolucji zagadnień fleksji i nauki o wyrazie (Czelakowska 2010), która w założeniu miała być dopełnieniem jego badań.

Zainteresowanie Skarżyńskiego dziejami myśli przejawiało się również w innych pracach, wśród których warto choć wspomnieć książkę o powstaniu słowotwórstwa opisowego i kształtowaniu się jego metodologii (1999) oraz artykuł poświęcony wieloletniej polemice Witolda Doroszewskiego z tezami Ferdynanda de Saussure’a, która toczyła się na różnych poziomach: od terminologiczno-pojęciowego, przez metodologiczny, kończąc zaś na fundamencie światopoglądowym (Skarżyński 2001b).

2. Orientacja zyskana dzięki wcześniejszym studiom z zakresu historii lingwistyki sprawiła, że Skarżyński miał świadomość, że wiedza o początkach językoznawstwa naukowego w Polsce jest wciąż niesatysfakcjonująca. Choć bowiem ogólne tło okresu zostało nakreślone np. w wymienionych pracach Stanisława Urbańczyka $(1968,1975,1993)$ i Ireny Bajerowej $(1987,1999)$, uzupełniającą zaś lekturą mogła być 
wspomnieniowa książka Kazimierza Nitscha (1960), to znaczna część szczegółów organizowania się środowiska językoznawczego wciąż była nieznana.

2.1. Wobec braku źródeł publikowanych naturalne - z punktu widzenia historyka nauki - było skoncentrowanie uwagi na materiałach archiwalnych, przede wszystkim na spuściznach językoznawców. Już pierwsza z nich - materiały Henryka Ułaszyna, odnalezione w Archiwum PAN w Warszawie przez Magdalenę Smoczyńską miała ogromną wartość poznawczą, przybliżającą realia nauki i życia naukowego w Polsce i na świecie w pierwszym trzydziestoleciu XX w. Stała się też podstawą pierwszego z serii opracowań korespondencji dawnych badaczy (Skarżyński, Smoczyńska 2007).

Zbiór, liczący 156 listów i kart pocztowych Jana Baudouina de Courtenay do H. Ułaszyna oraz 11 brulionów listów Ułaszyna do tegoż z lat 1898-19294, jest świadectwem niezwykłej relacji, która trwała aż do śmierci Baudouina. O genezie tych listów tak pisze Skarżyński:

Henryk Ułaszyn poznał Baudouina w 1897 r. w Krakowie, gdzie przyjechał dla dalszych studiów. Wrażenie, jakie wywarł na nim profesor, musiało być bardzo silne, skoro młody człowiek postanowił zająć się językoznawstwem. Uczęszczał na wykłady Baudouina i był uczestnikiem jego privatissimów w mieszkaniu przy ul. Pędzichów. Korespondencja zaczęła się w rok później, kiedy Ułaszyn wyjechał na stypendium do Wiednia [...].

Po wyjeździe Baudouina do Petersburga Ułaszyn uznał, że nie ma czego dłużej szukać w Krakowie (wspomina o tym w jednym z listów do Kazimierza Nitscha), i na dalsze studia pojechał do Lipska. Od tego czasu korespondencja stała się już regularna, a Baudouin stał się swego rodzaju doradcą, przewodnikiem (nie tylko naukowym, ale i życiowym) Ułaszyna (Skarżyński 2008a: 9-10).

Z listów poznajemy bliżej nie tylko wydarzenia z biografii obu uczonych: okoliczności usunięcia Baudouina z Uniwersytetu Jagiellońskiego, historię „Brückneriady", czyli trwającego w latach 1907-1911 naukowo-sądowego sporu między Ułaszynem a Aleksandrem Brücknerem, angażującego w tym okresie znaczną część środowiska językoznawczego, nie tylko zresztą polskiego, szczegóły rozprawy sądowej Baudouina z 1914 r. wytoczonej mu w związku z broszurą o autonomii, a po wojnie sprawy wolnomyślicielskie i konflikty obu korespondentów ze środowiskami endeckimi. Zwracają uwagę także liczne wątki naukowe, sądy Baudouina o ludziach i rozmaitych pracach, a przede wszystkim list z 1921 r., w którym Baudouin ocenia swoją prywatną drogę naukową i raz jeszcze uzasadnia, czemu w istocie uważa się za samouka ${ }^{5}$.

\footnotetext{
4 Listy, które otrzymywał Jan Baudouin de Courtenay, niestety spłonęły w Warszawie w 1944 r.

5 Więcej na ten temat może powiedzieć Autobiogram Baudouina, przetłumaczony i opublikowany przez Mirosława Skarżyńskiego (2016a), o którym mowa w dalszej części artykułu.
} 
Listy pozwalają też zrozumieć, dlaczego właśnie te dwie osoby zogniskowały uwagę Skarżyńskiego w późniejszych latach: przy licznych różnicach charakterów „obaj są bowiem wolnomyślicielami, bronią swobód obywatelskich, bezpardonowo tępią wszelką blagę naukową, a także nieuczciwość i przejawy obłudy" (Skarżyński, Smoczyńska 2007: VI). Obaj przy tym za bezkompromisowość głoszonych poglądów popadają w konflikty z otoczeniem i - w pełni świadomie - ponoszą ich rozmaite konsekwencje (zob. więcej: Skarżyński 2008a).

Niemożliwe jest dziś już odtworzenie kolejności, w jakiej rodziło się zainteresowanie Skarżyńskiego Baudouinem, jego pracami i publicystyką. Być może zresztą znajomość jego publikacji nienaukowych Profesor pogłębiał też przy okazji przygotowywania przypisów do korespondencji z Ułaszynem. O tym, że Baudouinowskie poglądy w jakiś sposób wydawały się atrakcyjne i Skarżyńskiemu, świadczyć może opublikowanie jeszcze w tym samym roku wyboru jego pism publicystycznych $\mathrm{z}$ lat 1898-1927 pt. Miejcie odwage myślenia... (Baudouin de Courtenay 2007). Ich tematyka porusza zagadnienia polityczne, moralne, narodowościowe, mówi o nauczaniu i wychowaniu, ale również o literaturze i jej roli w społeczeństwie. Pozycję centralną zajmują jednak kwestie światopoglądowe, związane z etyką i wolnością sumienia oraz walką o - jak powiemy współcześnie - prawa człowieka (ibid.: 12-23). Skarżyński, poza wyborem reprezentatywnych tekstów z różnych kręgów tematycznych publicystyki Baudouina i opatrzeniem ich przypisami, napisał też obszerny wstęp, w którym cieniując rysy charakteru uczonego, przedstawił jego postać w mniej oczywistym świetle.

Baudouin ukazuje się w tym tekście z jednej strony jako racjonalista, przejawiający szacunek dla faktów i odrzucający istnienie przekonań niedających się udowodnić, jako sprzecznych z ludzkim rozumem (czego konsekwencją była postawa agnostyczna), z drugiej zaś strony jako etyk, który jako podstawę działania zaleca kierowanie się „poczuciem sprawiedliwości” (ibid.: 13-14). To ostatnie winno być jego zdaniem przesłanką do równego traktowania wszystkich ludzi i unikania ich krzywdzenia. Lektura pism dowodzi też rygoryzmu etycznego Baudouina i przekonania, że bez względu na okoliczności należy mówić i pisać prawdę. Zarazem, na co zwraca uwagę Skarżyński, w parze z tymi cechami uczonego szła tolerancja dla odmiennych poglądów, a nawet widoczna chęć ich zrozumienia. Autor wstępu próbuje zatem wyjaśnić, dlaczego postawa Baudouina przysparzała mu tak licznych przeciwników:

Był Baudouin de Courtenay bez wątpienia publicystą ostrym, głoszącym prawdy niepopularne, co - zwłaszcza w społeczeństwie żywiącym się mitami, kompleksami i urazami - musiało przysparzać mu już nie tylko przeciwników, ale wręcz wrogów, zwłaszcza wśród posiadaczy patentów na prawdę jedyną, zawodowych obrońców wiary i polskości. Musiał drażnić ostentacyjnie podkreślany indywidualizm, niechęć do "myślenia stadowego", nieidentyfikowanie się więc z popularnymi postawami, wreszcie bezlitosne demaskowanie kierujących myśleniem stereotypów, wokół 
których buduje się ideologie, wiodące w ostatecznym rozrachunku do wojen i rewolucji. Innych drażnił zapewne piętnowaniem oportunizmu. Stąd napaści na niego, o których wspominałem wcześniej [...] (ibid.: 25).

2.2. Obie edycje z 2007 r. (Baudouin de Courtenay 2007; Skarżyński, Smoczyńska 2007) należy uznać za decydujące o dalszej pracy naukowej Skarżyńskiego, skupionej już wyłącznie na historii polskiego językoznawstwa. Jeszcze w 2006 r. profesor rozpoczyna starania o udostępnienie materiałów archiwalnych ze spuścizn językoznawców w Archiwum Nauki PAN i PAU w Krakowie. Jako pierwsze przygotowuje do wydania stosunkowo niewielkie zbiory nieznanych wcześniej listów Baudouina do Nitscha (56 kart pocztowych i listów) oraz do Jana Rozwadowskiego (33 karty i listy), pominięte w zbiorze listów Baudouina do różnych adresatów wydanym przez Edwarda Stachurskiego (2002). Choć oba zbiory pierwotnie publikuje w „LingVariach" (2007; 2008b), ostatecznie uznaje za konieczne opracowanie większej edycji, powiązanej osobami piszących. $Z$ jednej strony umożliwi ona bowiem przyszłym badaczom lepsze poznanie tworzącego się środowiska językoznawczego, z drugiej zaś będzie mieć tę przewagę nad pojedynczymi publikacjami, że pokaże ten obraz z różnych punktów widzenia, a więc w sposób najbardziej obiektywny. Ostatecznie współautorska edycja pt. Materiały do dziejów polskiego językoznawstwa, obejmująca lata 1898-1955 i osiem zbiorów korespondencji pięciu językoznawców: J. Baudouina de Courtenay, H. Ułaszyna, K. Nitscha, J. Rozwadowskiego i J. Łosia ukazuje się drukiem dopiero po czterech latach (Czelakowska, Skarżyński 2011).

Warto w tym miejscu przypomnieć, że formowanie się językoznawstwa naukowego w Polsce rozpoczęła działalność kilku zaledwie osób, które mogły pracować w sprzyjających warunkach politycznych autonomii galicyjskiej. Umożliwiały one funkcjonowanie dwóch polskich uniwersytetów - w Krakowie i Lwowie - oraz Akademii Umiejętności, która dawała oparcie organizacyjne i wydawnicze. W $1876 \mathrm{r}$. do Krakowa przybył Lucjan Malinowski, założyciel pierwszego periodyku językoznawczego „Sprawozdania Komisji Językowej AU” oraz pierwszego na ziemiach polskich seminarium słowiańskiego (od 1888 r.), którego uczniami byli m.in. Stanisław Dobrzycki, Edward Klich, Kazimierz Nitsch i Roman Zawiliński, a więc pierwsi uczniowie tzw. szkoły krakowskiej, która zasiliła później nowe ośrodki naukowe w wolnej Polsce. W latach 1894-1899 wykłady na Uniwersytecie Jagiellońskim oraz privatissima prowadził Baudouin de Courtenay. Uczestniczyli w nich zarówno Rozwadowski, który w 1895 r., już jako doktor, powrócił z Lipska, jak i odbywający studia w Krakowie Nitsch i Ułaszyn. Kilka lat później, bo już po wyjeździe Baudouina, znalazł się tu jeszcze Jan Łoś, który w 1902 r. objął wykłady na uniwersytecie oraz pracownię Słownika staropolskiego.

Rozwadowski, Nitsch i Łoś pozostali związani z Krakowem i tutaj tworzyli pierwsze organy polskiej nauki o języku (slawistyczne i polonistyczne): wychodzące od 1901 r. „Materiały i Prace Komisji Językowej Akademii Umiejętności”, 
zaplanowany jako uzupełnienie "MPKJ" o materiały krytyczne periodyk bibliograficzny „Rocznik Slawistyczny” (1908 r.), w którym publikowali wówczas cenieni badacze językoznawstwa europejskiego, dalej zaś popularnonaukowy „Poradnik Językowy” (wspólnie z Zawilińskim) i od 1913 r. „Język Polski”. Również w Krakowie po odzyskaniu niepodległości zaczęli organizować Towarzystwo Miłośników Języka Polskiego i Polskie Towarzystwo Językoznawcze. Stały kontakt ze środowiskiem krakowskim utrzymywali też Ułaszyn (najpierw z Lipska, gdzie się doktoryzował i pracował jako „prywatny uczony”, po 1920 r. zaś ze Lwowa i z Poznania) i Baudouin (z Petersburga, a później z Warszawy), obaj często publikujący w dwóch pierwszych (tj. stricte naukowych) periodykach i niejednokrotnie pośredniczący w kontaktach ze slawistami z innych krajów.

Znajomość nawet krótko nakreślonego w ten sposób kontekstu pozwala lepiej zrozumieć ześrodkowanie prac edytorskich Skarżyńskiego z jednej strony na badaczach związanych z Krakowem $^{6}$, z drugiej zaś na ich spuściznach prywatnych, zachowały one bowiem więcej informacji o wydarzeniach tego okresu niż dokumenty instytucjonalne. Sam Skarżyński w artykule omawiającym korespondencję Nitscha i Ułaszyna konieczność opracowania materiałów źródłowych uzasadniał w ten sposób:

Przechowywane w archiwach listy polskich językoznawców z przełomu XIX i XX w. stanowią ciągle niewykorzystane, znane słabo lub w poszczególnych wypadkach nieznane całkiem źródła do dziejów polskiej lingwistyki. Tymczasem o wartości korespondencji przekonują choćby edycje listów Baudouina de Courtenay zarówno te wcześniejsze [...], jak i ostatnie [...]. Oczywiście korespondencja nie jest w tym wypadku źródłem podstawowym ani pierwszorzędnym, ale przynosi często wiele szczegółów, których z naturalnych przyczyn nie ma w dokumentach oficjalnych. Tak więc jeśli pozostałe po naszych poprzednikach prace naukowe dają obraz rozwoju myśli językoznawczej, a dokumenty instytucjonalne wiedzę o dziejach instytucji naukowych, to korespondencja prywatna pozwala poznać przede wszystkim samych uczonych, ale też często uzupełnia szczegółami dane z dwóch pierwszych źródeł (Skarżyński 2011: 71).

Dalsze badania Skarżyńskiego, w których poszukiwał informacji o początkach działalności instytucjonalnej lat 2o. XX w., pokazały, że wbrew oczekiwaniom i chęciom korespondencja w niektórych przypadkach bywa źródłem konkretniejszym od szczątkowo zachowanych dokumentów. Nie jest to zresztą rzecz zaskakująca. Mówimy bowiem o okresie, gdy konferencje i zjazdy naukowe były rzadkością, a korespondencja stanowiła podstawowy sposób utrzymania naukowego i zawodowego kontaktu, umożliwiającego przede wszystkim bycie na bieżąco z literaturą naukową

6 We Lwowie aż do okresu Polski Odrodzonej językoznawstwo polonistyczne rozwijało się stosunkowo powoli, co było spowodowane m.in. słabszą naukowo obsadą czy też tym, że zabrakło tam zdolniejszych organizatorów (Bajerowa 1987). 
(tą właśnie drogą przekazywano sobie bowiem nadbitki wydawanych prac). W okresie tworzenia struktur organizacyjnych językoznawstwa pozwalała zaś zgrać działania w poszczególnych ośrodkach czy też wspólnie rozstrzygać sprawy, które wymagały dyskusji.

Oczywiście Skarżyński był świadom, że korzystanie z korespondencji jako źródła informacji wymaga szczególnie ostrożnego i krytycznego podejścia wobec jej częstej niekompletności, subiektywizmu, a nierzadko emocjonalności i pochopności reakcji korespondujących. Uznawał jednak, że najbardziej szkodliwy - z punktu widzenia badacza historii nauki - subiektywizm można w pewnym przynajmniej stopniu wyeliminować, czerpiąc ze źródeł dodatkowych:

[...] nie sposób jednak poprzestać na jednoosobowym źródle, sposób przedstawienia tego czy innego faktu i jego interpretacja jest zawsze w jakimś stopniu subiektywna. Ta świadomość narzuca z kolei konieczność objęcia badaniami korespondencji także innych osób tworzących dane środowisko (ibid.: 89).

Tymczasem doraźność reakcji w niektórych wypadkach wnosiła też wartość pozytywną, ze względu na możliwość swoistej introspekcji w przeżycia autora listu i poznania sytuacji, które dziś oglądamy z dużego dystansu, oczami osób zainteresowanych i zaangażowanych bezpośrednio:

Listy [...] pozwalają wiele zdarzeń poznać „od wewnątrz”, w chwili dziania się, tak jak je widzieli ich uczestnicy. Można też znaleźć w tych materiałach wiele faktów szerzej nieznanych, a zarazem osobistych przekonań i opinii o ludziach i sprawach, nieujawnianych na ogół gdzie indziej. Listy są więc kapitalnym materiałem do poznania osobowości uczonych (czasem również ich spraw prywatnych), stosunków między nimi oraz warunków środowiskowych, w których przyszło im pracować (Czelakowska, Skarżyński 2011: 8).

2.3. Uzyskane w ten sposób informacje uzupełniały „oficjalną” wiedzę o J. Baudouinie de Courtenay, H. Ułaszynie, K. Nitschu, J. Rozwadowskim i J. Łosiu. Zwłaszcza trzy pierwsze postacie, ich dokonania naukowe i niedostępne wcześniej lub zapomniane już nieco prace powracały w artykułach, biogramach i edycjach.

Baudouin de Courtenay przez kilka lat ogniskował zainteresowania badawcze Skarżyńskiego przede wszystkim jako człowiek i publicysta (2008a, 2010, 2012b). Zainteresowanie tym aspektem „baudouinologii” nie odwiodło jednak Skarżyńskiego od badania także dorobku lingwistycznego Baudouina, zwłaszcza jego koncepcji opisu języka i językoznawstwa. Pewne wspólne cechy charakteryzowały zresztą, zdaniem Profesora, zarówno jego sposób pracy naukowej, jak i szersze działania:

Trzeba zauważyć, że istnieje duże podobieństwo Baudouina-językoznawcy i Baudouina-publicysty. Zarówno w pracach lingwistycznych, jak w publicystyce znajdujemy tę samą metodę postępowania: podstawą są fakty, w pierwszym wypadku językowe, w drugim wypadku, ogólnie rzecz ujmując, polityczne. Jedne i drugie ujmuje 
Baudouin na szerszym tle, w powiązaniu z innymi i dopiero tak prowadzona analiza jest podstawą dla wniosków ogólniejszych. Uczony nie przestaje być uczonym tylko dlatego, że wychodzi poza swą dyscyplinę, że zamiast faktów językowych rozważa fakty społeczne. I tam, i tu obowiązuje ta sama ścisłość myślenia i unikanie wniosków, dla których zabrakłoby faktograficznego uściślenia (Skarżyński 2012b: 56).

Szczególnie ważnym wkładem w poszerzenie znajomości Baudouina lingwisty jest przygotowywana przez wiele lat, po części przy okazji opracowywania materiałów do wykładów akademickich, edycja Tekstów mniej znanych, związanych z zagadnieniami języka i nauki o nim. Zbiór został pomyślany jako uzupełnienie istniejących już polskich wyborów prac Baudouina i wydany jako II tom Materiałów do dziejów polskiego językoznawstwa w serii „Biblioteka LingVariów” (Skarżyński 2016a). Wśród 13 tekstów, z których dziewięć Skarżyński przetłumaczył z rosyjskiego, znajdziemy m.in. pierwszy petersburski wykład Baudouina (z 1870 r.), będący odpowiednikiem współczesnych wykładów habilitacyjnych, oraz jego Autobiogram opublikowany w 1897 r. w słowniku rosyjskich pisarzy i uczonych Siemiona A. Wiengierowa. Oba teksty zasługują na uwagę przede wszystkim ze względu na przedstawione w nich tezy zawierające poglądy Baudouina na język i językoznawstwo, w tym drugim zaś również szczegółową bibliografię i bardzo krytyczną ocenę dotychczasowych osiągnięć. Wszystkie prace i teksty Baudouina, które przypomniał, przetłumaczył i przedrukował Skarżyński, łączy przy tym wspólny mianownik: dostrzegał on w nich pole zbyt słabo zagospodarowane przez polskich badaczy.

Podobnie postać H. Ułaszyna powraca w bibliografii prac Skarżyńskiego kilkakrotnie: poznajemy go jako ucznia Baudouina, pozostającego z nim w przyjacielskiej wręcz relacji, jako publicystę, wreszcie jako profesora kolejno trzech uniwersytetów: lwowskiego, poznańskiego i łódzkiego (Skarżyński 2006, 2012c; Skarżyński, Walczak w: Ułaszyn 2009: 9-37). Uczony, znany dziś przede wszystkim z pracy doktorskiej dotyczącej przegłosu, artykułu Słowotwórstwo, opublikowanego w językowym tomie Encyklopedii Polskiej AU i włączonego później do tzw. gramatyki PAU z 1923 r., oraz z wprowadzenia pojęcia i terminu morfonem (wówczas o kształcie: morfonema $)^{7}$, jest chyba najbarwniejszą postacią przedwojennego środowiska językoznawczego. Świadczą o tym nie tylko listy, ale też Wspomnienia, które Skarżyński przygotował do druku na podstawie zachowanych fragmentów zapisków Ułaszyna (Ułaszyn 2010), opatrując obszernym wstępem i przypisami. I choć, jak zwykle w publikacjach tego typu, autorskie oceny wydarzeń są w nich nierzadko subiektywne i niesprawiedliwe, Wspomnienia są kapitalnym źródłem wiedzy o ówczesnym życiu ziemiaństwa na Kijowszczyźnie, o stosunkach akademickich i codzienności, a przede wszystkim - o ludziach na przełomie wieków w Kijowie, Krakowie,

$7 \quad$ W zakresie edycji prac również w wypadku Ułaszyna Skarżyński przypomniał (we współpracy z Bogdanem Walczakiem) zapomniane dziś nieco studia i „przyczynki leksykalne” z zakresu onomastyki i socjolingwistyki (Ułaszyn 2009). 
a później także w Lipsku; wreszcie, choć w bardzo ograniczonym stopniu - o czasach lwowskich, poznańskich i powojennych.

Kazimierz Nitsch przysłużył się pracom badawczym Skarżyńskiego dzięki największej chyba z zachowanych spuścizn epistolarnych, do której należą m.in. listy Baudouina (1905-1928), Łosia (1909-1920) i Ułaszyna (1905-1952), opublikowane we wspomnianym tomie Materiałów do dziejów polskiego językoznawstwa z 2011 r., oraz obszerna korespondencja z uczennicą, Antoniną Obrębską-Jabłońską, z lat 1925-1958 (Skarżyński, Smułkowa 2018). Objętość tej ostatniej, przygotowanej do druku wraz z Elżbietą Smułkową i wydanej w trzeciej części Materiałów..., to dwa potężne tomy (1075 listów i kart pocztowych) liczące po opublikowaniu ponad 1200 stron. Książka jest nieprzebranym źródłem do badań historii językoznawstwa polonistycznego i slawistycznego. Korespondencja to szczególna, nie tylko ze względu na swoją objętość, ale też okres trwania i zakres poruszanych wątków, wśród których znajdują się zarówno sprawy stricte zawodowe, jak i osobiste, a nakreślone tło pozwala szerzej poznać dzieje polskiej inteligencji w wieku XX, w tym podczas okupacji i 13 powojennych lat, które tak bardzo zmieniły polską rzeczywistość (ibid.: VII). Większy jest też w niej stopień otwartości Nitscha niż wobec innych adresatów, co pokazuje rysy jego osobowości w świetle odmiennym niż w poświęconych mu dotychczas publikacjach. Szczególnie interesujący staje się ów obraz na tle pozostałych listów Nitscha, pozwala bowiem nie tylko poznać go lepiej jako człowieka, ale też docenić ogrom pracy, jaki wkładał w łączenie działalności dydaktycznej i naukowej z wszelkimi sprawami organizacyjnymi związanymi z TMJP (w tym działalnością kół pozakrakowskich), a także z pracami redakcyjnymi - najpierw w „MPKJ” i „Roczniku Slawistycznym”, a później w „Języku Polskim” (zob. Skarżyński 2011: 80-82) .

Wśród prac Skarżyńskiego opisujących ludzi, ich losy i dokonania naukowe znajdują się też przyczynki biograficzne autorów słabiej dziś czasem pamiętanych, jak Karol Appel (Skarżyński 2013), a także kilka biogramów w Polskim słowniku biograficznym: Henryka Sucheckiego, Ignacego Steina i Witolda Taszyckiego (Skarżyński 2005, 2008c, 2019b).

3. Artykuły Mirosława Skarżyńskiego poświęcone zagadnieniom organizowania się polskiego językoznawstwa oraz działań mających na celu jego wzmocnienie i stabilizację układają się w uporządkowany cykl tematyczny: plany językoznawstwa naukowego u początków Polski Odrodzonej, powstawanie TMJP, tworzenie PTJ i narodziny Studium Słowiańskiego przy UJ (Skarżyński 2014, 2016b, 2018, 2019a).

Artykuł W jaki sposób wzmocnić u nas językoznawstwo? (Skarżyński 2014) ukazuje plany rozwoju dziedziny w czasie, gdy po wycofaniu się z Warszawy Rosjan

8 Ciekawostką jest udostępnienie przez Skarżyńskiego drukiem także jedynego nagrania wykładu Kazimierza Nitscha, wygłoszonego w Olsztynie w 1956 r. przy okazji jubileuszu 50-lecia jego pierwszej bytności na Warmii, odnalezionego przypadkiem w zbiorach dialektologicznych UAM (Skarżyński 2012a). 
tworzone były polski uniwersytet i politechnika oraz formowało się trzecie na ziemiach polskich środowisko akademickie. W tym czasie (1917 r.) Komitet Kasy im. Mianowskiego rozpisał ankietę mającą na celu zbadanie stanu nauki polskiej, a więc polskich instytucji naukowych, charakterystyki ich działalności, ich poziomu naukowego, „użyteczności dla Polski”, ale też potrzeb materialnych, wydawniczych itd. (ibid.: 252). Odpowiedzi - artykuły 90 pracowników nauki, które ukazały się w nowym czasopiśmie „Nauka Polska. Jej Potrzeby, Organizacja i Rozwój” w 1918 i 1919 r. - stanowią początek polskiego naukoznawstwa. Omówiona przez Skarżyńskiego zawartość artykułów nadesłanych przez działających badaczy języka: J. Rozwadowskiego, K. Nitscha, S. Szobera i A. Brücknera, może się dziś wydawać zaskakująca pod względem liczebności i precyzyjności planów rozwoju dyscypliny i jej organizacji instytucjonalnej w nowych warunkach, zwłaszcza że zgodnie z rachubami Nitscha działających językoznawców w Polsce było wówczas około 20 (ibid.: 256). W inwentarzu potrzeb znalazło się nie tylko opracowanie wyczerpującej gramatyki historycznej języka polskiego, całej serii podręczników językoznawczych oraz podręczników szkolnych, słownika polszczyzny literackiej XIX w., ale nawet słownika etymologicznego i onomazjologicznego. Jednak zdaniem Skarżyńskiego ten plan prac należało już wtedy liczyć na lata, biorąc pod uwagę zagadnienia nie tylko językoznawstwa polonistycznego, ale też slawistycznego, indoeuropeistycznego i in., tak by móc dorównać do poziomu europejskiego (ibid.: 266-267).

Wątkiem, który łączy owe plany naukowe z powstaniem TMJP, jest znalezienie w nich potwierdzenia, że już w czasie pisania artykułu dla Kasy Mianowskiego (ok. 1917 r.?) Nitsch nosił się z myślą powołania „szeroko założonego "Towarzystwa językoznawczego" czy »Tow[arzystwa] miłośników języka»"9 (za: Skarżyński 2014: 257, 2018: 209). Miało ono służyć szerzeniu wiedzy językowej wśród tzw. wykształconego ogółu i skupiać osoby zainteresowane polszczyzną, zaś uzyskane składki miały wspierać wydawanie „JP”, który stałby się głównym narzędziem popularyzowania owej wiedzy - co jest zgodne z późniejszą formułą Towarzystwa. W artykule o historii TMJP udało się Skarżyńskiemu udowodnić - na podstawie korespondencji zachowanej w Nitschowskim archiwum - jeszcze jedną ważną, a pomijaną dotychczas we wszystkich źródłach informację, a mianowicie to, że inicjatywę założenia TMJP przypisać należało Andrzejowi Gawrońskiemu, orientaliście i badaczowi sanskrytu, współzałożycielowi Polskiego Towarzystwa Orientalistycznego i PTJ. On też zapewne wpłynął na ostateczny kształt nazwy stowarzyszenia, był twórcą jego statutu i inspiratorem niemal wszystkich działań organizacyjnych, w tym rozpowszechniania idei wśród nauczycieli, a także tworzenia oddziałów pozakrakowskich (Skarżyński 2018: 206-210). Źródła, na których artykuł został oparty, wskazują, że również zmiana formuły „JP”, której celem miało być uprzystępnienie czasopisma niefachowej publiczności, została przyjęta przez redaktorów pod wpływem Gawrońskiego (ibid.: 213 i nast.). 
Początki PTJ, na skutek lakoniczności protokołów zebrań towarzystwa, były dotychczas znane słabo - nie rozszerzały bowiem tej wiedzy ani artykuły rocznicowe w „Biuletynie Polskiego Towarzystwa Językoznawczego”, ani książka Urbańczyka (1993). Również w tym wypadku wiedzę pogłębiają listy z archiwum Nitscha i Ułaszyna, potwierdzające m.in. udział A. Gawrońskiego w pracach założycielskich i tworzeniu statutu PTJ oraz pokazujące dyskusje nad jego pierwotnym kształtem, a także sprawy związane $\mathrm{z}$ organizacją pierwszego walnego zebrania. Na podstawie dostępnych dokumentów Skarżyński wykazał też - w kontrze do twierdzenia Urbańczyka o „stowarzyszeniu językoznawców zawodowych” - że i PTJ na początku był organizacją otwartą, nawet jeśli większość stanowili w nim językoznawcy (Skarżyński 2016b: 298-299).

Znacznie bogatsze źródła zachowały się wśród akt wydziałowych UJ w odniesieniu do dziejów Studium Słowiańskiego UJ. Mimo to, choć instytucja ta wychowała większość slawistów pokolenia przedwojennego, a wielu również po wojnie (zob. więcej Skarżyński 2019a: 11-12), do niedawna nie miała niemal żadnego opisu. Obszerny artykuł Skarżyńskiego przedstawia jej genezę, wykazując, że obok naukowych przyczyn stworzenia placówki równie ważne były cele polityczne. Miała więc ona służyć nie tylko szerzeniu wiedzy o Słowiańszczyźnie, ale też budowaniu polskich wpływów w krajach słowiańskich. Nie mniej interesujące wydają się częściowo zrekonstruowany przebieg „rozgrywki” między Krakowem a Warszawą o ostateczne miejsce powstania placówki oraz szczegóły związane z pierwszym okresem jej funkcjonowania i trudnościami, z jakimi musiano się zmierzyć. Pokrótce opisane zagadnienia organizowania Studium Słowiańskiego Skarżyński badał przez wiele miesięcy, także w tym wypadku korzystając z korespondencji jako materiałów źródłowych. Monografia na ten temat pozostała jednak w sferze zamierzeń.

4. Mirosław Skarżyński nigdy nie zdecydował się przedstawić swojej koncepcji badania historii językoznawstwa (por. Miodunka 2020). Nie powinno to zresztą zaskakiwać. Zapewne uważał, że procedura działania musi być w tym wypadku analogiczna do metod przyjmowanych w naukach historycznych, a więc przede wszystkim opisywania faktów z przeszłości na podstawie bezpośrednich wiadomości źródłowych, rzadziej pośredniego ustalania faktów (por. Topolski 1984: 377-391). Z tego też powodu za zadanie priorytetowe uznawał wydawanie źródeł do przyszłych dziejów polskiej lingwistyki. Sam nacisk badawczy położył na opracowanie korespondencji z przeszłości, którą stawiał wysoko przede wszystkim przez możliwość poznania osobowości i losów dawnych uczonych oraz warunków, w których rodziło się polskie językoznawstwo naukowe. Jeśli podejść do rzeczy tylko liczbowo, to w trzech współautorskich edycjach udostępnił ponad 1800 stron korespondencji (nie licząc części edytorskich i biogramów informujących o postaciach z listów), a do wartości tej należy dodać jeszcze blisko pięćsetstronicowe Wspomnienia H. Ułaszyna (2010). Tymczasem opracowanie zbioru koresponden- 
cji to nie tylko jej odczytanie i przepisanie, ale przede wszystkim przygotowanie współgrających ze sobą przypisów ${ }^{10}$.

Ostatni z opisywanych „segmentów”, tj. dzieje instytucji, dobrze pokazuje jednak, że Skarżyński podejmował też próby rekonstruowania interesujących go wydarzeń na podstawie szczątkowo zachowanych dokumentów i informacji pochodzących z korespondencji, choć hipotezy niepoparte źródłami i niemożliwe do udowodnienia redukował, by omijać domysły. Niemniej łączenie faktów i ukazywanie ich na szerszym tle pozwoliło mu np. uzupełnić sporo szczegółów okoliczności powstania pierwszych polskich towarzystw językowych. W jeszcze większym stopniu owo przechodzenie od materiału do uogólnień i teorii widoczne było w pracach poświęconych dziejom myśli.

Rzeczą ważniejszą od samej metody wydaje się jednak różnokierunkowość badań Profesora jako historyka językoznawstwa: dzieje opisów języka, sylwetki i losy uczonych, konstytuowanie się organów i instytucji naukowych, wreszcie edycje listów, wspomnień i słabiej znanych, a wciąż wartościowych dokonań ówczesnych badaczy. Dzięki temu nie tylko powiększył on wiedzę o dziejach lingwistyki w Polsce i przybliżył postaci nierzadko już zapomnianych uczonych i ich codziennych spraw, ale też pozostawił model badawczy i punkt odniesienia dla wszystkich działających na tym polu.

\section{Literatura}

Bajerowa I., 1987, Językoznawstwo polonistyczne, [w:] B. Suchodolski (red.), Historia nauki polskiej, t. IV: 1863-1918, cz. III: Rozwój nauk szczegółowych, Wrocław, s. 802-819.

Bajerowa I., 1999, Językoznawstwo polonistyczne, [w:] A. Sródka (red.), Historia nauki polskiej. Wiek XX (Nauki filologiczne), Warszawa, s. 203-228.

Baudouin de Courtenay J., 2007, Miejcie odwage myślenia... Wybór pism publicystycznych z lat 1898-1927, opracował, wstępem i przypisami opatrzył M. Skarżyński, „Biblioteka Klasyki Polskiej Myśli Politycznej”, t. XVIII, Kraków.

Czela Kowska A., 2010, Opisy fleksyjne w gramatykach polskich lat 1817-1939, „Biblioteka LingVariów”, t. 6, Kraków.

CzelakowsKa A., Skarżý́ski M., 2011, Materiały do dziejów polskiego językoznawstwa. Listy Jana Niecisława Baudouina de Courtenay, Jana Łosia, Kazimierza Nitscha, Jana Michała Rozwadowskiego, Henryka Ułaszyna, „Biblioteka LingVariów”, t. 8, Kraków.

GrZEGORCZYKOWA R., 1964, Słowotwórstwo w językoznawstwie polskim XIX wieku (Z historii polskiej nauki o budowie wyrazów. II), „Prace Filologiczne” XVIII, cz. 3, s. 203-221.

KAWYN-Kurz Z., 1964, Kształtowanie się metod analizy słowotwórczej wyrazu w językoznawstwie polskim XX wieku (Z historii polskiej nauki o budowie wyrazów. III), „Prace Filologiczne" XVIII, cz. 3, s. 223-241.

10 Szczególne wrażenie może zrobić korespondencja Nitscha i Antoniny Obrębskiej-Jabłońskiej, w której znalazło się 1700 przypisów, jednak również tom korespondencji pięciu językoznawców, opracowany wspólnie z piszącą te słowa, zawiera około 500 nazwisk, tj. 43 strony notek biograficznych, połączonych z kilkuset przypisami do tomu. 
Miodunka W., 2020, Rozważania nad koncepcja językoznawstwa polskiego, „LingVaria” nr 2 (30), s. 193-207, https://doi.org/10.12797/LV.15.2020.30.15.

Nitsch K., 1960, Ze wspomnień językoznawcy, Kraków.

Podracki J., 1982, Koncepcje składniowe w gramatykach języka polskiego (od O. Kopczyńskiego do Z. Klemensiewicza), Warszawa.

Puzynina J., 1964, Słowotwórstwo $w$ gramatykach staropolskich (Z historii polskiej nauki o budowie wyrazów. I), „Prace Filologiczne” XVIII, cz. 3, s. 185-202.

Robinson M.A., 2014, Losy elity akademickiej. Rosyjska slawistyka od 1917 r. do początku lat 3o., przeł. M. Skarżyński, Warszawa.

SKARŻYŃSKi M., 1994, Części mowy i ich kategorie w gramatykach polskich XIX i XX wieku (1817-1938), „Rozprawy Habilitacyjne UJ” nr 281, Kraków.

SKARŻYŃski M., 1999, Powstanie i rozwój polskiego słowotwórstwa opisowego, Kraków.

SKARŻYŃSKi M., 2001a, W kręgu gramatyk polskich XIX i XX wieku, Kraków.

SKarżyński M., 2001b, W. Doroszewski wobec Kursu językoznawstwa ogólnego Ferdynanda de Saussure'a, [w:] Z. Cygal-Krupowa (red.), Studia językoznawcze. Dar przyjaciót i uczniów dla Zofii Kurzowej, Kraków, s. 321-331.

SKarżý́ski M., 2005, Stein Ignacy, pseud. Żegota (1875-1964), [w:] Polski słownik biograficz$n y$, t. XLIII/2, z. 177, Warszawa - Kraków, s. 291-293.

SkARŻy ́́ski M., 2006, O prof. Henryku Ułaszynie (w 50. rocznicę śmierci), „LingVaria” nr 2 (2), S. 65-73.

SKarżý́sKi M., 2007, Nieznane listy Jana Baudouina de Courtenay do Kazimierza Nitscha $z$ lat 1905-1928, cz. I: 1905-1910, „LingVaria” nr 1 (3), s. 167-190, cZ. II: 1911-1928, „LingVaria” nr 2 (4), s. 149-174.

SkARŻYŃski M., 2008a, Między Petersburgiem, Krakowem i Lipskiem. O listach Jana Baudouina de Courtenay do Henryka Ułaszyna, „Seminaria Naukowe Wrocławskiego Towarzystwa Naukowego", t. 7 (58), s. 9-16.

Skarżý́ski M., 2008b, Nieznane listy Jana Baudouina de Courtenay do Jana M. Rozwadowskiego, „LingVaria” nr 1 (5), s. 205-232.

Skarżý́ski M., 2008c, Suchecki Henryk Ignacy (1811-1872), [w:] Polski słownik biograficzny, t. XLV/2, Z. 185, Warszawa - Kraków, s. 243-246.

SKarżyŃski M., 2010, Jan Baudouin de Courtenay and Henryk Ułaszyn in light of their correspondence, „Studia Linguistica Universitatis Iagiellonicae Cracoviensis” nr 127, s. 79-100.

SKarżý́ski M., 2011, O listach Kazimierza Nitscha do Henryka Ułaszyna, [w:] R. Majkowska, T. Filip (red.), Kazimierz Nitsch (1874-1958). Materiały z posiedzenia naukowego $w$ dniu 20 czerwca 2008 r., „W Służbie Nauki” nr 18, Kraków, s. 71-90.

SkARŻyŃski M., 2012a, Kazimierz Nitsch w Olsztynie w 1956 r. Odnaleziony „wykład z dialektologii”, „LingVaria” nr 2 (14), s. 195-205.

SKarżYŃsKi M., 2012b, Nowoczesne państwo i społeczeństwo w poglądach Jana Baudouina de Courtenay, [w:] D. Ulicka, W. Bolecki (red.), Strukturalizm w Europie Środkowej $i$ Wschodniej. Wizje i rewizje, Warszawa, s. 54-65.

Skarżyński M., 2012c, Poznańskie lata Henryka Ułaszyna, „Poznańskie Studia Polonistyczne. Seria Językoznawcza”, t. 19 (39), z. 1, „Prace Instytutu Filologii Polskiej Uniwersytetu im. Adama Mickiewicza", s. 199-220.

Skarżyński M., 2013, Przypomnienie Karola Appla. Przyczynki biograficzne, „Poradnik Językowy" nr 7, s. 5-20. 
SKARŻYŃSKI M., 2014, „W jaki sposób wzmocnić u nas językoznawstwo?”. Lingwistyka polska w wypowiedziach uczonych $z$ lat 1918-1919, „LingVaria” nr 2 (18), s. 251-269, https://doi. org/10.12797/LV.09.2014.18.16.

SKARŻYŃski M. (oprac.), 2016a, Materiały do dziejów polskiego językoznawstwa. II: Jan Baudouin de Courtenay. Teksty mniej znane, wybór, przekład i opracowanie..., „Biblioteka LingVariów", t. 21, Kraków.

SKarżý́ski M., 2016b, Powstanie Polskiego Towarzystwa Językoznawczego, „LingVaria” nr 2 (22), s. 295-304, https://doi.org/10.12797.LV.11.2016.22.19.

Skarżyński M., 2018, Przyczynki do historii Towarzystwa Miłośników Języka Polskiego, „LingVaria” nr 1 (25), s. 205-217, https://doi.org/10.12797/LV.13.2017.25.15.

SKarżYŃski M., 2019a, Geneza i początki Studium Słowiańskiego UJ, „LingVaria” nr 1 (27), s. 11-33, https://doi.org/10.12797/LV.14.2019.27.01.

Skarżyński M., 2019b, Taszycki Witold Klemens Józef (1898-1979), [w:] Polski słownik biograficzny, t. LII/4, z. 215, Warszawa - Kraków, s. 583-587.

SKarżyński M., Smoczyńska M. (oprac.), 2007, Listy Jana Baudouina de Courtenay do Henryka Ułaszyna z lat 1898-1929, „Biblioteka LingVariów”, t. 1, Kraków.

SKarżyński M., SmuŁKowa E. (oprac.), 2018, Materiały do dziejów polskiego językoznawstwa. III: Korespondencja Kazimierza Nitscha i Antoniny Obrębskiej-Jabłońskiej 1925-1958, cz. 1-2, „Biblioteka LingVariów”, t. 26, Kraków.

StACHURSki E. (oprac.), 2002, Jan N. Baudouin de Courtenay. Listy z lat 1870-1927, Kraków. Topolski J., 1984, Metodologia historii, wyd. 3 popr. i uzup., Warszawa.

UŁASZYN H., 2009, Studia onomastyczne i socjolingwistyczne, wstęp i dobór tekstów M. Skarżyński, B. Walczak, „Klasycy Nauki Poznańskiej”, t. 41, Poznań.

UŁASZYN H., 2010, Z Kopiowatej na katedry uniwersyteckie. Wspomnienia, z rękopisu opracował, opatrzył przypisami i wydał M. Skarżyński, „Biblioteka LingVariów”, t. 7, Kraków.

URBAŃCZY K S., 1968, Językoznawstwo polskie pierwszej połowy XIX wieku, [w:] idem, Szkice $z$ dziejów języka polskiego, Warszawa, s. 370-412.

UrbańcZy K S., 1975, Językoznawstwo polskie w latach 1850 do 1918 r., [w:] M. Kvapil (red.), Prace $z$ déjin slavistiky II, Praha, s. 27-41.

UrваŃczy K S., 1993, Dwieście lat polskiego językoznawstwa (1751-1950), Kraków.

\section{Scholars and Their Fates... - Mirosław Skarżyński as a Researcher of the History of Polish Linguistics \\ Summary}

The paper presents Mirosław Skarżyński’s studies in the field of the history of Polish linguistics, and their consecutive phases: history of ideas (concepts, grammatical descriptions); history of people researchers who once laid the foundations of scientific linguistics; and history of institutions. The emerging picture reveals that the research procedure adopted by Skarżyński was analogous to the method of historical sciences which demand that facts of the past should be described based on direct source information. In this perspective, the description of Polish linguistics must have been preceded by a considerable number of detailed studies, and publication of sources. Skarżyński put particular emphasis on the edition of memoirs and correspondence from the past. He saw in them not merely a complementary fond of information in research on the history of ideas and institutions, but primarily a road to understanding the personalities and fates of past scholars, as well as the conditions in which Polish scientific linguistics was born. 